\title{
Thermophysical properties of the garnet, grossular: $\mathrm{Ca}_{3} \mathrm{Al}_{2} \mathrm{Si}_{3} \mathrm{O}_{12}{ }^{a}$
}

\author{
EDGAR F. WESTRUM, JR., \\ Department of Chemistry \\ ERIC J. ESSENE, and DEXTER PERKINS, III \\ Department of Geology and Mineralogy, University of Michigan, \\ Ann Arbor, Michigan 48109, U.S.A.
}

(Received 15 July 1977; in revised form 21 June 1978)

\begin{abstract}
The heat capacity of a gem-quality mineralogical sample of grossular: $\mathrm{Ca}_{3} \mathrm{Al}_{2} \mathrm{Si}_{3} \mathrm{O}_{12}$ has been determined by equilibrium adiabatic-shield calorimetry from 5 through $600 \mathrm{~K}$ and adjusted to the stoichiometric terminal-component grossular by a new entropy-adjustment scheme delineated in the paper. At $298.15 \mathrm{~K}$ the observed values of $C_{p}, S^{\circ},\left\{H^{\circ}(T)-\right.$ $\left.H^{\circ}(0)\right\} / T$, and $-\left\{G^{\circ}(T)-H^{\circ}(0)\right\} / T$ are $79.00,61.61,37.92$, and $23.69 \mathrm{cal}_{\mathrm{th}} \mathrm{K}^{-1} \mathrm{~mol}^{-1}$. The entropy adjusted to terminal component grossular is $60.88 \mathrm{cal}_{\mathrm{th}} \mathrm{K}^{-1} \mathrm{~mol}^{-1}$. The results are combined with higher-temperature differential-scanning calorimetric values of Perkins $e t$ al. and of Robie $e t$ al. to provide thermodynamic values over greatly extended ranges of temperature.
\end{abstract}

\section{Introduction}

Grossular: $\mathrm{Ca}_{3} \mathrm{Al}_{2} \mathrm{Si}_{3} \mathrm{O}_{12}$, an important representative of the garnet-structure group, not only occurs in calcareous rocks formed over a wide variety of pressure and temperature but also is found in a variety of synthetic systems. Surprisingly, in view of importance of both natural and synthetic garnets, particularly YIG (yttrium iron garnet) and YAG (yttrium aluminum garnet), measured heat capacities are not available over adequate temperature ranges to permit evaluation of practical thermodynamic functions. Thermodynamic calculations of phase equilibria involving garnets are limited by this lack of reliable data. The only available values ${ }^{(1)}$ were calculated from phase equilibria approximately determined at pressures of 1 to $2 \mathrm{GPa}$ and 1300 to $1700 \mathrm{~K}^{(2,3)}$ Large uncertainties in such values are occasioned by extrapolation to $300 \mathrm{~K}$. This lack of reliability is further enhanced by significant uncertainties in the location of the experimental equilibria in these sluggish systems. Because of the expected errors in such widely used thermochemical data for grossular, we measured the low- and intermediate-temperature heat capacity of mineralogical grossular to provide reliable thermodynamic results for phase- and reaction-equilibrium calculations.

- This research was supported in part by the Chemical Thermodynamics Program of the Chemistry Section of the National Science Foundation under Contract No. GP-42525X. 
Because even the best mineralogical samples are far from stoichiometrically pure, we developed a scheme for adjusting the thermodynamic results to correspond to that of the pure substance. We consider this method to be widely applicable and more reliable than conventional methods.

\section{Experimental}

\section{SAMPLE PROVENANCE}

Since an attempted synthesis of grossular initially results in a product of low-purity even on a micro-scale, ${ }^{(4)}$ we sought well characterized pure natural grossular as close as possible to the end-member composition, $\mathrm{Ca}_{3} \mathrm{Al}_{2} \mathrm{Si}_{3} \mathrm{O}_{12}$.

We obtained some unusually pure gem-quality grossular which occurs as veins in a serpentine at Thetford, Quebec, from Professor A. L. Boettcher of the Department of Geosciences, Pennsylvania State University. The gem quality of the individual crystals, of 1 to $9 \mathrm{~mm}$ typical dimensions, allowed rapid hand picking of some $40 \mathrm{~g}$ of pure garnet free from visible inclusions. This material was ideal for calorimetric studies because of rapid thermal equilibration of the large crystals. Obtaining an equivalent synthetic $\mathrm{Ca}_{3} \mathrm{Al}_{2} \mathrm{Si}_{3} \mathrm{O}_{12}$ would have required prohibitively difficult experiments at high pressures. Microprobe analysis of the major and minor elements revealed no zoning or inhomogeneities down to the $5 \mu \mathrm{m}$ scale. Wet-chemical analysis of the garnet ${ }^{(5)}$ yielded the values in table 1 and, in terms of atomic composition, in table 2. The proximate selection of end-member components in table 3 indicates that the garnet is approximately 91 mass per cent pure grossular with several other garnet components in solid solution. This analysis has been confirmed by electronmicroprobe analysis. Such solutions are comparable to those of natural samples used for heat-capacity measurements by King, Kelley, and co-workers ${ }^{(8-13)}$ and are acceptable when adequate adjustment is made for deviation from ideal stoichiometry.

TABLE 1. Analysis of Thetford garnet sample in terms of mass fractions $w$ of constituent oxides

\begin{tabular}{llllll}
\hline Oxide & $10^{2} w$ & Oxide & $10^{2} w$ & Oxide & $10^{2} w$ \\
\hline $\mathrm{SiO}_{2}$ & 39.20 & $\mathrm{FeO}$ & 1.81 & $\mathrm{MgO}$ & 0.24 \\
$\mathrm{CaO}$ & 35.50 & $\mathrm{MnO}$ & 0.65 & $\mathrm{H}_{2} \mathrm{O}$ & $0.19{ }^{a}$ \\
$\mathrm{Al}_{2} \mathrm{O}_{3}$ & 21.80 & $\mathrm{TiO}_{2}$ & 0.25 & $\mathrm{Fe}_{2} \mathrm{O}_{3}$ & 0.00 \\
\hline
\end{tabular}

a See discussion in text.

TABLE 2. Atomic composition of grossular (Thetford garnet) sample normalized to 12 oxygen atoms

\begin{tabular}{lccccccccc}
\hline Elements & $\mathrm{Si}$ & $\mathrm{Al}$ & $\mathrm{Ti}$ & $\mathrm{Mg}$ & $\mathrm{Mg}$ & $\mathrm{Fe}$ & $\mathrm{Mn}$ & $\mathrm{Ca}$ & $\mathrm{OH}$ \\
\hline Atoms & $2.98_{5}$ & $\underbrace{1.95_{7}}$ & $0.01_{4}$ & $0.01_{4}$ & $\underbrace{0.02_{7}}$ & $0.11_{5}$ & $0.04_{1}$ & $2.89_{7}$ & $0.09_{6}$ \\
Total atoms & $2.98_{5}$ & & $1.98_{5}$ & & & $3.08_{0}$ & & $0.09_{6}$ \\
\hline
\end{tabular}


TABLE 3. Analysis of grossular sample in terms of end-member components and entropy increments thereof at $298.15 \mathrm{~K}$

$\left(\mathrm{cal}_{\mathrm{th}}=4.184 \mathrm{~J}\right)$

\begin{tabular}{llccc}
\hline Composition & Name & Code & $x_{i}{ }^{a}$ & $\frac{\Delta S_{\mathrm{i}}{ }^{\circ}}{\mathrm{cal}_{\mathrm{tb}} \mathrm{K}^{-1} \mathrm{~mol}^{-1}}$ \\
\hline $\mathrm{Ca}_{3} \mathrm{Al}_{2} \mathrm{Si}_{2} \mathrm{O}_{8}(\mathrm{OH})_{4}$ & hydrogrossular & hg & 0.024 & $-22.29^{\mathrm{c}, ~ d}$ \\
$\mathrm{Mg}_{3} \mathrm{Al}_{2} \mathrm{Si}_{3} \mathrm{O}_{12}$ & pyrope & pp & 0.004 & $9.07^{\circ}$ \\
$\mathrm{Mn}_{3} \mathrm{Al}_{2} \mathrm{Si}_{3} \mathrm{O}_{12}$ & spessartine & sp & 0.014 & $-15.3^{\circ}$ \\
$\mathrm{Fe}_{3} \mathrm{Al}_{2} \mathrm{Si}_{3} \mathrm{O}_{12}$ & almandine & al & 0.038 & $-9.98^{\circ}$ \\
$\mathrm{Ca}_{3} \mathrm{MgTiSi}_{3} \mathrm{O}_{12}$ & Mg-melanite & mm & 0.014 & $-6.3^{\circ}$ \\
$\mathrm{Ca}_{3} \mathrm{Fe}_{2} \mathrm{Si}_{3} \mathrm{O}_{12}$ & andradite & an & 0.000 & - \\
$\mathrm{Ca}_{3} \mathrm{Al}_{2} \mathrm{Si}_{3} \mathrm{O}_{12}$ & grossular & gr & 0.906 & - \\
\hline
\end{tabular}

${ }^{a}$ Mole fraction of $i$ th end-member in sample. Mineralogical end members were selected to express the composition of the Thetford garnet. We have determined the values of the mole fractions of non-grossular components directly from table 2 and have chosen the grossular mole fraction so that the sum of all mole fractions is unity.

- The entropy increment of the $i$ th end-member relative to grossular (see text).

c Reference 6.

${ }^{a}$ Reference 7.

\section{CALORIMETRIC TECHNIQUES}

Adiabatic intermittent-heating equilibrium heat-capacity measurements from 5 to $350 \mathrm{~K}$ were made in calorimeter W-22 $\left(93.4 \mathrm{~cm}^{3}\right.$; gold-plated copper; platinum resistance thermometer A-3) in the Mark-II cryostat, ${ }^{(14)}$ while those in the 300 to $500 \mathrm{~K}$ range were made in the Mark-IV thermostat ${ }^{(15)}$ using calorimeter W-22P $\left(84 \mathrm{~cm}^{3}\right.$; silver; platinum resistance thermometer A-5). Pressures of 1.3 and $7.8 \mathrm{kPa}$ of purified helium gas were used within the calorimeters to facilitate thermal equilibration. All determinations of mass, potential, current, time, and temperature were based ultimately upon calibrations by the National Bureau of Standards.

\section{Results and discussion}

\section{HEAT CAPACITY OF SAMPLE}

The heat-capacity measurements in both ranges are listed in table 4 in chronological sequence so that temperature increments used in these determinations can usually be inferred from adjacent mean temperatures. These results have been adjusted for curvature, i.e. for the correction between $\Delta H / \Delta T$ for the finite increments employed and the limit $\left(C_{p}\right)$ of this quantity as $\Delta T$ approaches zero. The values in this table represent those on the sample as run; no adjustment has been made to the composition of pure grossular. However, they have been adjusted to a molar mass of $450.454 \mathrm{~g}$ $\mathrm{mol}^{-1}$, which is that of pure grossular rather than to a molar mass corresponding to the solution composition. The heat capacities of the empty calorimeters represent from 65 per cent of the total at $15 \mathrm{~K}$ to 47 per cent at $100 \mathrm{~K}$ and remain at about 35 per cent above $150 \mathrm{~K}$. The curve of heat capacity against temperature is of sigmate shape without anomalies. 
TABLE 4. Heat capacity of grossular $\left(\mathrm{cal}_{\mathrm{th}}=4.184 \mathrm{~J}\right)$

\begin{tabular}{|c|c|c|c|c|c|c|c|}
\hline$\frac{T}{\mathrm{~K}} \quad \overline{\mathrm{cal}_{\mathrm{t}}}$ & $\frac{C_{p}}{\mathrm{k}^{-1} \mathrm{~mol}^{-1}}$ & $\frac{T}{\mathbf{K}} \overline{\mathrm{cal}_{\mathrm{tb}}}$ & $\frac{C_{p}}{-^{-1} \mathrm{~mol}^{-1}}$ & $\frac{T}{\mathrm{~K}} \overline{\mathrm{cal}_{\mathrm{th}}}$ & $\frac{C_{p}}{x^{-1} \mathrm{~mol}^{-1}}$ & $\frac{T}{\mathrm{~K}} \overline{\mathrm{cal}_{\mathrm{th}}}$ & $\frac{C_{\mathrm{p}}}{\mathrm{C}^{-1} \mathrm{~mol}^{-1}}$ \\
\hline \multicolumn{8}{|c|}{ Low-temperature data-Mark $\amalg$ cryostat } \\
\hline \multicolumn{2}{|c|}{ Series I } & \multicolumn{2}{|c|}{ Series II } & 325.23 & 83.59 & 16.83 & 0.138 \\
\hline 54.09 & 4.861 & 200.11 & 56.32 & 335.16 & 84.82 & 18.49 & 0.181 \\
\hline 61.80 & 7.008 & 212.10 & 59.71 & 345.58 & 86.01 & 20.56 & 0.250 \\
\hline 70.27 & 9.629 & 223.61 & 62.83 & & & 23.19 & 0.385 \\
\hline 79.48 & 12.82 & 234.71 & 65.67 & \multicolumn{2}{|c|}{ Series IV } & 25.81 & 0.512 \\
\hline 89.61 & 16.63 & 245.47 & 68.32 & 5.28 & 0.002 & 27.83 & 0.633 \\
\hline 99.84 & 20.49 & 255.95 & 70.70 & 7.91 & 0.007 & 29.82 & 0.782 \\
\hline 110.39 & 24.64 & 266.17 & 72.84 & \multicolumn{2}{|r|}{0.001} & 32.29 & 1.007 \\
\hline 121.31 & 29.01 & 276.41 & 74.95 & \multicolumn{2}{|c|}{ Series V } & 35.39 & 1.345 \\
\hline 132.06 & 33.22 & 286.69 & 76.89 & 5.01 & 0.003 & 37.71 & 1.634 \\
\hline 142.21 & 37.11 & 297.01 & 78.97 & 6.11 & 0.006 & 39.78 & 1.912 \\
\hline 151.85 & 40.68 & 307.40 & 80.71 & 7.47 & 0.006 & 42.99 & 2.451 \\
\hline 161.40 & 44.08 & 317.59 & 82.41 & 8.66 & 0.021 & 46.88 & 3.199 \\
\hline 171.42 & 47.48 & 327.64 & 84.02 & 9.77 & 0.025 & 51.82 & 4.285 \\
\hline 182.47 & 51.04 & 337.54 & 85.38 & 11.07 & 0.042 & 57.61 & 5.772 \\
\hline 194.57 & 54.70 & \multirow{2}{*}{\multicolumn{2}{|c|}{ Series III }} & 12.65 & 0.051 & & \\
\hline 206.92 & 58.28 & & & 14.14 & 0.079 & & \\
\hline 218.73 & 61.55 & 315.17 & 81.84 & 15.43 & 0.107 & & \\
\hline \multicolumn{8}{|c|}{ Intermediate-temperature data-Mark IV thermostat } \\
\hline \multicolumn{2}{|c|}{ Series I } & \multicolumn{2}{|c|}{ Series II } & 456.54 & 98.34 & 532.92 & 103.67 \\
\hline 302.11 & 71.62 & 380.75 & 90.70 & 466.62 & 99.20 & 542.78 & 104.39 \\
\hline 312.04 & 81.33 & 391.03 & 91.87 & 476.63 & 100.03 & 552.59 & 104.99 \\
\hline 321.83 & 82.89 & 401.21 & 93.13 & 486.57 & 100.78 & & \\
\hline 330.15 & 84.15 & 411.30 & 94.10 & 496.44 & 101.48 & Ser & $\mathrm{S} \mathrm{V}$ \\
\hline 340.15 & 85.61 & 421.30 & 95.16 & & & 546.44 & 104.30 \\
\hline 350.03 & 87.02 & 431.21 & 96.12 & Seri & s IV & 556.25 & 104.68 \\
\hline 359.80 & 88.22 & 441.05 & 97.09 & 487.57 & 100.52 & 565.99 & 105.39 \\
\hline 369.87 & 89.57 & 450.82 & 97.89 & 494.54 & 101.14 & 574.90 & 105.83 \\
\hline 380.25 & 90.75 & & & 503.37 & 101.76 & 584.31 & 107.55 \\
\hline \multirow[t]{2}{*}{390.53} & 91.95 & \multicolumn{2}{|c|}{ Series III } & 513.03 & 102.42 & 595.06 & 107.80 \\
\hline & & 446.39 & 97.41 & 523.01 & 103.01 & & \\
\hline
\end{tabular}

Apart from questions of chemical composition, the heat-capacity values of table 4 are considered to be characterized by standard deviations of 0.08 per cent above $25 \mathrm{~K}$; below this temperature the uncertainty gradually increases to 0.3 per cent at $10 \mathrm{~K}$, and to 10 per cent at $5 \mathrm{~K}$ due to the decreasing sensitivity of the platinum resistance thermometer.

\section{THERMODYNAMIC FUNCTIONS OF (IMPURE) GROSSULAR}

Values of the heat capacity of grossular as measured at selected temperatures have been presented in table 5 on the basis of a smoothed curve fitted by digital computer using the least-squares method. The thermodynamic functions integrated from the smoothed curve are also presented in the same table. Above $100 \mathrm{~K}$ the values of all the functions are considered to be reliable to 0.06 per cent for the composition measured. It is again emphasized that table 5 (like table 4 ) is based upon the molar mass of pure grossular. 
TABLE 5. Thermodynamic functions of grossular ${ }^{a}$ $\left(\mathrm{cal}_{\mathrm{th}}=4.184 \mathrm{~J}\right)$

\begin{tabular}{|c|c|c|c|c|}
\hline$\frac{T}{\mathrm{~K}}$ & $\frac{C_{\mathrm{p}}}{\mathrm{cal}_{\mathrm{th}} \mathrm{K}^{-1} \mathrm{~mol}^{-1}}$ & $\frac{S^{\circ}(T)-S^{\circ}(0)}{\mathrm{cal}_{\mathrm{tg}} \mathrm{K}^{-1} \mathrm{~mol}^{-1}}$ & $\frac{H^{\circ}(T)-H^{\circ}(0)}{\mathrm{cal}_{\text {如 }} \mathrm{mol}^{-\mathrm{z}}}$ & $\frac{-\left\{G^{\circ}(T)-H^{\circ}(0)\right\} / T}{\mathrm{cal}_{\text {th }} \mathrm{K}^{-1} \mathrm{~mol}^{-1}}$ \\
\hline $\begin{array}{r}5 \\
10 \\
15 \\
20 \\
25\end{array}$ & $\begin{array}{l}0.019 \\
0.070 \\
0.118 \\
0.222 \\
0.432\end{array}$ & $\begin{array}{l}0.003 \\
0.034 \\
0.071 \\
0.117 \\
0.187\end{array}$ & $\begin{array}{l}0.0141 \\
0.255 \\
0.713 \\
1.527 \\
3.110\end{array}$ & $\begin{array}{l}0.0003 \\
0.0090 \\
0.0235 \\
0.0408 \\
0.0626\end{array}$ \\
\hline $\begin{array}{l}30 \\
35 \\
40 \\
45 \\
50\end{array}$ & $\begin{array}{l}0.780 \\
1.291 \\
1.976 \\
2.839 \\
3.878\end{array}$ & $\begin{array}{l}0.294 \\
0.451 \\
0.666 \\
0.947 \\
1.298\end{array}$ & $\begin{array}{l}6.076 \\
11.18 \\
19.28 \\
31.24 \\
47.96\end{array}$ & $\begin{array}{l}0.0916 \\
0.1311 \\
0.1838 \\
0.2523 \\
0.3387\end{array}$ \\
\hline $\begin{array}{r}60 \\
70 \\
80 \\
90 \\
100\end{array}$ & $\begin{array}{c}6.441 \\
9.543 \\
13.029 \\
16.75 \\
20.55\end{array}$ & $\begin{array}{l}2.222 \\
3.442 \\
4.941 \\
6.688 \\
8.623\end{array}$ & $\begin{array}{l}99.05 \\
178.6 \\
291.2 \\
439.9 \\
626.4\end{array}$ & $\begin{array}{l}0.5715 \\
0.8910 \\
1.3008 \\
1.8001 \\
2.360\end{array}$ \\
\hline $\begin{array}{l}110 \\
120 \\
130 \\
140 \\
150\end{array}$ & $\begin{array}{l}24.55 \\
28.51 \\
32.42 \\
36.22 \\
39.92\end{array}$ & $\begin{array}{l}10.770 \\
13.076 \\
15.51 \\
18.06 \\
20.68\end{array}$ & $\begin{array}{r}851.9 \\
1117.3 \\
1422.0 \\
1765.3 \\
2146.1\end{array}$ & $\begin{array}{l}3.025 \\
3.766 \\
4.575 \\
5.446 \\
6.374\end{array}$ \\
\hline $\begin{array}{l}160 \\
170 \\
180 \\
190 \\
200\end{array}$ & $\begin{array}{l}43.49 \\
46.93 \\
50.22 \\
53.37 \\
56.37\end{array}$ & $\begin{array}{l}23.37 \\
26.11 \\
28.89 \\
31.69 \\
34.50\end{array}$ & $\begin{array}{l}2563.3 \\
3015.5 \\
3501.3 \\
4019.4 \\
4568.2\end{array}$ & $\begin{array}{r}7.352 \\
8.375 \\
9.437 \\
10.535 \\
11.663\end{array}$ \\
\hline $\begin{array}{l}210 \\
220 \\
230 \\
240 \\
250\end{array}$ & $\begin{array}{l}59.24 \\
61.96 \\
64.55 \\
67.01 \\
69.34\end{array}$ & $\begin{array}{l}37.32 \\
40.14 \\
42.96 \\
45.75 \\
48.54\end{array}$ & $\begin{array}{l}5146.4 \\
5752.5 \\
6385.2 \\
7043.1 \\
7724.9\end{array}$ & $\begin{array}{l}12.818 \\
13.996 \\
15.19 \\
16.41 \\
17.64\end{array}$ \\
\hline $\begin{array}{l}260 \\
270 \\
280 \\
290 \\
300\end{array}$ & $\begin{array}{l}71.56 \\
73.66 \\
75.65 \\
77.54 \\
79.33\end{array}$ & $\begin{array}{l}51.30 \\
54.04 \\
56.76 \\
59.44 \\
62.10\end{array}$ & $\begin{array}{r}8429.5 \\
9155.6 \\
9902.2 \\
10668.2 \\
11452.7\end{array}$ & $\begin{array}{l}18.88 \\
20.13 \\
21.39 \\
22.66 \\
23.93\end{array}$ \\
\hline $\begin{array}{l}273.15 \\
298.15\end{array}$ & $\begin{array}{l}74.29 \\
79.00\end{array}$ & $\begin{array}{l}54.90 \\
61.61\end{array}$ & $\begin{array}{r}9389 \\
11306\end{array}$ & $\begin{array}{l}20.53 \\
23.69\end{array}$ \\
\hline $\begin{array}{l}310 \\
320 \\
330 \\
340 \\
350\end{array}$ & $\begin{array}{l}81.03 \\
82.64 \\
84.17 \\
85.63 \\
87.01\end{array}$ & $\begin{array}{l}64.73 \\
67.33 \\
69.90 \\
72.43 \\
74.93\end{array}$ & $\begin{array}{l}12254.5 \\
13073.0 \\
13907.1 \\
14756.2 \\
15619\end{array}$ & $\begin{array}{l}25.20 \\
26.48 \\
27.75 \\
29.03 \\
30.31\end{array}$ \\
\hline $\begin{array}{l}400 \\
450 \\
500 \\
550 \\
600\end{array}$ & $\begin{array}{r}93.00 \\
97.76 \\
101.59 \\
104.59 \\
107.32\end{array}$ & $\begin{array}{r}86.96 \\
98.20 \\
108.70 \\
118.53 \\
127.74\end{array}$ & $\begin{array}{l}20126 \\
24899 \\
29886 \\
35044 \\
40340\end{array}$ & $\begin{array}{l}36.64 \\
42.87 \\
48.93 \\
54.82 \\
60.51\end{array}$ \\
\hline
\end{tabular}

- The table is based upon the molar mass of pure grossular: $M\left(\mathrm{Ca}_{3} \mathrm{Al}_{2} \mathrm{Si}_{3} \mathrm{O}_{12}\right)=450.454 \mathrm{~g} \mathrm{~mol}^{-1}$. 


\section{COMPARISON WITH OTHER DATA}

Kiseleva et al. ${ }^{(4)}$ used the inverse-temperature drop-calorimetry method of Holm et al. ${ }^{(16)}$ with a Tian-Calvet microcalorimeter as receiver over the range 700 to $1400 \mathrm{~K}$. The enthalpy increment between $298 \mathrm{~K}$ and the receiver temperature may then readily be determined on even a few milligrams of sample with a standard deviation of 2 per cent and an accuracy several times larger. We have shown the deviations of their data (after adjustment from the approximate 91 per cent "end member" proximate purity by our scheme discussed later) in figure 1 .

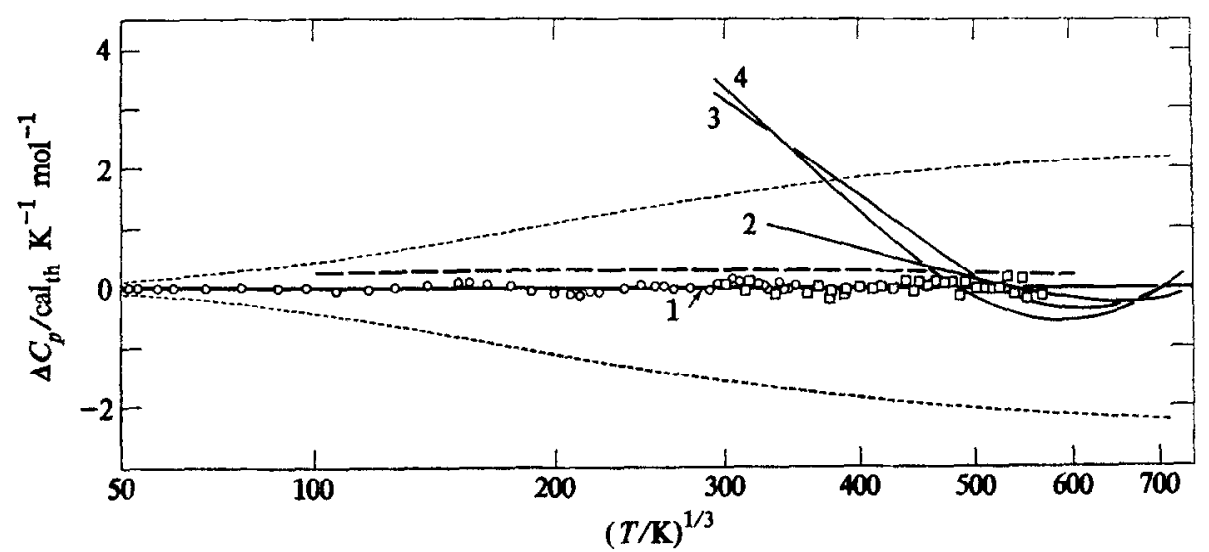

FIGURE 1. Deviations from the adjusted smoothed heat-capacity curve of this research (curve 1) taken from table 6 of $O$, low-temperature and $\square$, superambient-temperature points of this research. The dashed line represents the deviations of the apparent smoothed heat-capacity curve of this research taken from table 5. Curve 2 is the deviation of the d.s.c. data of Robie and Krupka. (17) Curve 3 is the deviation of the Tian-Calvet microcalorimetric data of Kiseleva et al. ${ }^{(4)}$ Curve 4 shows the d.s.c. data of Kiseleva et al. ${ }^{(4)}$ adjusted by the technique of this research. The dotted lines represent deviations from the adjusted smoothed curve of \pm 2 per cent.

Differential-scanning calorimetric values of Robie et al. ${ }^{(17)}$ over a more limited range on both a synthetic and a natural sample are also shown in figure 1 . These data accord well with those previously reported by the authors on the same apparatus using a portion of the sample from this research. ${ }^{(18)}$ They agree within the combined estimated uncertainty.

\section{ADJUSTMENT OF ENTROPY FOR IMPURITIES}

To calculate the effects of dissolved garnet-phase impurities on the thermophysical properties, we assumed that the observed entropy of our sample was equal to the sum of the entropies of the end-member garnets. The analysis of the calorimetric garnet sample given in table 1 is represented in table 2 in terms of the end-member components also shown in table 2.

Rather than adjust entropy values by deduction of the entropies of the oxides which contribute to the non-stoichiometry, as is frequently done, ${ }^{(8,19)}$ we prefer to use a summation technique for this adjustment since the impurities are certainly 
present in solid solution rather than as pure binary oxide phases. Hence, we account for the observed entropy $S_{\text {obs }}$ (i.e. the molar entropy calculated for the molar mass of the end-member-grossular in this instance-to which the thermodynamic functions are to be adjusted) at any temperature by the expression:

$$
S_{\mathrm{obs}}=W \sum_{i=1}^{i=n} x_{i} S_{i}
$$

in terms of the product of the mole fractions and the molar-entropy contributions of all the end-member components summed over all the $n$ end-member compositions involved. The factor $W$ involves the molar mass $M_{t}$ of the end-member compositions, and adjusts the observed molar entropy for the apparent molar mass of the sample to that $M_{y}$ of the end-member for which molar values are to be sought. Hence:

$$
W=M_{y} / \sum_{i=1}^{l=n} x_{i} M_{i}
$$

Separating out the pure composition $y$ for which molar values are sought and rearranging:

$$
S_{y}=S_{\mathrm{oba}} / W-\sum_{i=1}^{i=n-1} x_{i}\left(S_{i}-S_{y}\right)=S_{\mathrm{obs}} / W-\sum_{i=1}^{i=n-1} x_{i} \Delta S_{i},
$$

in which $\Delta S_{i}=\left(S_{i}-S_{y}\right)$, and each is referred to its own molar mass. For grossular we may then write (on the basis of and with the notation of table 2):

$$
\begin{aligned}
S_{\mathrm{gr}}=S_{\mathrm{obs}} / W-0.024 \Delta S(\mathrm{hg})-0.004 \Delta S(\mathrm{pp})-0.014 \Delta S(\mathrm{sp}) & -0.038 \Delta S(\mathrm{al})-0.014 \Delta S(\mathrm{~mm}) .
\end{aligned}
$$

Since entropies have not been experimentally determined for any of the end-member garnets, the $\Delta S(\mathrm{~mm})$-term was approximated, only for $\mathrm{Mg}$-melanite, by using entropy values for constituent binary oxides:

$$
\Delta S(\mathrm{~mm})=S(\mathrm{MgO})+S\left(\mathrm{TiO}_{2}\right)-S\left(\mathrm{Al}_{2} \mathrm{O}_{3}\right),
$$

in which $\Delta S(\mathrm{~mm})$ is the entropy contribution for the substitution of MgTi for $2 \mathrm{Al}$ ions.

A more accurate method of approximation involves adjustment in terms of measured entropies of isostructural phases for cations with similar coordination numbers by differencing the entropies of appropriate end-member phases. Thus:

$$
\begin{aligned}
\Delta S(\mathrm{al})=\frac{3}{2}\{S(\mathrm{fa})-S(\mathrm{Ca}-\mathrm{ol})\}, \quad \Delta S(\mathrm{pp})= & \frac{3}{2}\{S(\mathrm{fo})-S(\mathrm{Ca}-\mathrm{ol})\}, \\
& \text { and } \Delta S(\mathrm{sp})=\frac{3}{2}\{S(\mathrm{te})-S(\mathrm{Ca}-\mathrm{ol})\},
\end{aligned}
$$

in which fa represents fayalite $\left(\mathrm{Fe}_{2} \mathrm{SiO}_{4}\right)$, fo represents forsterite $\left(\mathrm{Mg}_{2} \mathrm{SiO}_{4}\right)$, te represents tephroite $\left(\mathrm{Mn}_{2} \mathrm{SiO}_{4}\right)$, and $\mathrm{Ca}$-ol represents $\mathrm{Ca}$-olivine $\left(\mathrm{Ca}_{2} \mathrm{SiO}_{4}\right)$. Moreover,

$$
\Delta S(\mathrm{hg})=2\left\{S(\mathrm{br})-\frac{1}{2} S(\mathrm{fo})\right\},
$$

in which br represents brucite $\mathrm{Mg}(\mathrm{OH})_{2}$. Examples of the $\Delta S_{i}$ values are given in table 2. Data for these were taken from references 1 and 16.

The oxidation state of the iron may represent an error in chemical analysis as the charge balance would be better if some of the iron were Fe(III). However, two 
independent chemical analyses found only Fe(II) present. If the iron were present entirely as $\mathrm{Fe}$ (III) the entropy correction term would be larger from that calculated above by $0.12 \mathrm{cal}_{\mathrm{th}} \mathrm{K}^{-1} \mathrm{~mol}^{-1}(0.3 \mathrm{per}$ cent) at $298.15 \mathrm{~K}$. $\dagger$

Another potential problem with our adjustment terms involves the presence, and if present the nature, of water (hydroxyl ion) in our sample. There are at least five possibilities and the relevant entropy correction term for its presence would be: (1) the analysis is correct and the garnet includes some hydrogrossular: $\Delta S(298.15 \mathrm{~K})$ $=-0.73_{4} \mathrm{cal}_{\mathrm{th}} \mathrm{K}^{-1} \mathrm{~mol}^{-1}$; (2) the analysis is correct and the garnet has fluid inclusions of water: $\Delta S(298.15 \mathrm{~K})=-1.04 \mathrm{cal}_{\mathrm{th}} \mathrm{K}^{-1} \mathrm{~mol}^{-1}$; (3) the analysis is correct and the garnet includes serpentine (serpentine was a second phase in the original impure materials): $\Delta S(298.15 \mathrm{~K})=-0.49_{9} \mathrm{cal}_{\mathrm{th}} \mathrm{K}^{-1} \mathrm{~mol}^{-1}$; (4) the analysis is correct and the sample contained serpentine eliminated by our hand picking it before we measured the heat capacity: $\Delta S(298.15 \mathrm{~K})=-0.57_{4} \mathrm{cal}_{\mathrm{th}} \mathrm{K}^{-1} \mathrm{~mol}^{-1}$; (5) the analysis is incorrect and there is no water present: $\Delta S(298.15 \mathrm{~K})=-0.64_{5}$ $\mathrm{cal}_{\text {th }} \mathrm{K}^{-1} \mathrm{~mol}^{-1}$.

We ignore possibility (2) since we found no discontinuity in the entropy curve at the $\mathrm{H}_{2} \mathrm{O}(\mathrm{s})=\mathrm{H}_{2} \mathrm{O}(\mathrm{l})$ equilibrium temperature. We have assumed that the small amount of $\mathrm{OH}^{-}$is present as hydrogrossular. Regardless of the specific corrections, the revised entropy values for pure grossular are within $0.3 \mathrm{cal}_{\mathrm{th}} \mathrm{K}^{-1} \mathrm{~mol}^{-1}(0.5 \mathrm{per}$ cent) of the entropy at standard conditions insofar as the water (hydroxyl) adjustment is involved.

\section{STANDARD ENTROPY OF GLOSSULAR}

The adjustment of the apparent standard entropy for the grossular composition measured to that for pure grossular using the adjustment equation in the immediately preceding section together with the $\Delta S_{i}$ values from table 2 indicates

$$
\Delta S_{\mathrm{gr}}^{\circ} / \mathrm{cal}_{\mathrm{th}} \mathrm{K}^{-1} \mathrm{~mol}^{-1}=S_{\mathrm{obs}}^{\circ} / W-\sum x_{i} \Delta S_{i}=60.87,
$$

as the adjusted value.

Adjustment of the enthalpy by the same method (with similar approximations and estimates) leads to a value of $\left\{H^{\circ}(298.15 \mathrm{~K})-H^{\circ}(0)\right\}$ of $11.250 \mathrm{kcal}_{\mathrm{th}} \mathrm{mol}^{-1}$, and the corresponding value of $-\left\{G^{\circ}(298.15 \mathrm{~K})-H^{\circ}(0)\right\} / T$ is $-23.14 \mathrm{cal}_{\mathrm{th}} \mathrm{K}^{-1} \mathrm{~mol}^{-1}$. A similar procedure serves for the heat capacities.

Adjustments at other temperatures were accomplished by a similar procedure at each temperature. Below about $100 \mathrm{~K}$ the scheme is not reliable. A summary of values of thermodynamic properties adjusted to the composition of grossular is presented in table 6 .

The standard deviations of our adjusted $S^{\circ}(T), C_{p}^{\circ}(T)$, and $\left\{G^{\circ}(T)-H^{\circ}(0)\right\} / T$ values are presumed to be within $\pm 0.2 \mathrm{cal}_{\mathrm{th}} \mathrm{K}^{-1} \mathrm{~mol}^{-1}$ for terminal members, but further determinations will be useful in providing a more accurate assessment of this uncertainty.

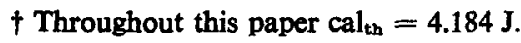


TABLE 6. Smoothed thermodynamic functions adjusted to pure ideal grossular ${ }^{a}$ $\left(\mathrm{cal}_{\mathrm{th}}=4.184 \mathrm{~J}\right)$

\begin{tabular}{|c|c|c|c|c|c|}
\hline$T$ & $\begin{array}{c}\text { Apparent } \\
C_{p}\end{array}$ & $C_{p}$ & $\begin{array}{c}\text { Adjusted } \\
S^{\circ}(T)-S^{\circ}(0)\end{array}$ & $H^{\circ}(T)-H^{\circ}(0)$ & $-\left\{G^{\circ}(T)-H^{\circ}(0)\right\} / T$ \\
\hline$\overline{\mathbf{K}}$ & $\mathrm{cal}_{\mathrm{th}} \mathrm{K}^{-1} \mathrm{~mol}^{-1}$ & $\mathrm{cal}_{t \mathrm{~h}} \mathrm{~K}^{-1} \mathrm{~mol}^{-1}$ & $\overline{\mathrm{cal}_{\mathrm{th}}} \mathrm{K}^{-1} \mathrm{~mol}^{-1}$ & $\mathrm{kcal}_{\mathrm{th}} \mathrm{mol}^{-1}$ & $\mathrm{cal}_{\text {th }} \mathrm{K}^{-1} \mathrm{~mol}^{-1}$ \\
\hline 100 & 20.55 & 20.33 & 8.16 & 0.613 & 2.033 \\
\hline 200 & 56.37 & 56.12 & 33.87 & 4.533 & 11.21 \\
\hline 298.15 & 79.00 & 78.73 & 60.88 & 11.243 & 23.17 \\
\hline 300 & 79.33 & 79.06 & 61.37 & 11.391 & 23.40 \\
\hline 400 & 93.00 & 92.73 & 86.15 & 20.04 & 36.06 \\
\hline 500 & 101.6 & 101.3 & 107.8 & 29.77 & 48.29 \\
\hline 600 & 107.3 & 107.1 & 126.8 & 40.20 & 59.84 \\
\hline 700 & - & 110.9 & 143.6 & 51.08 & 70.63 \\
\hline 800 & - & 113.7 & 158.5 & 62.30 & 80.62 \\
\hline 900 & - & 115.9 & 172.1 & 73.72 & 90.19 \\
\hline 1000 & - & 117.6 & 184.3 & 85.44 & 98.86 \\
\hline
\end{tabular}

${ }^{a}$ See text.

${ }^{\mathrm{n}}$ Sample as run (table 5), no adjustment for composition.

The authors appreciate the continuing financial support for these thermodynamic studies by the National Science Foundation. We also thank Professor A. L. Boettcher of Pennsylvania State University for sample provenance and acknowledge the cooperation of Drs James J. Bartel, Silverio Henriquez, and Harmas L. Kiwia in assisting in making these determinations.

\section{REFERENCES}

1. Robie, R. A.; Waldbaum, D. R. Thermodynamic properties of minerals and related substances at $298.15 \mathrm{~K}\left(25.0^{\circ} \mathrm{C}\right)$ and one atmosphere $(1.013 \mathrm{bar})$ pressure and at higher temperatures. Geol. Surv. Bull. 1259. U.S. Government printing office: Washington 1968.

2. Hays, J. F. The System CaO- $\mathrm{Al}_{2} \mathrm{O}_{3}-\mathrm{SiO}_{2}$ at High Pressures and High Temperatures. Ph.D. Thesis, Harvard University, Cambridge, Massachusetts. 1966.

3. Hays, J. F. Am. Mineralogist 1966, 51, 1524.

4. Topor, N. D.; Kiseleva, I. A.; Mel'chakova, L. V. Geokhimiya 1972, 9, 335; Kiseleva, I. A.; Topor, N. D.; Mel'chakova, L. V. Geokhimiya 1972, 9, 1372.

5. Boettcher, A. L. Personal communication. 1974.

6. Kelley, K. K.; King, E. G. Contributions to the data on theoretical metallurgy. XIV. Entropies of the elements and inorganic compounds. U.S. Bur. Mines Bull. No. 592, 1961.

7. King, E. G.; Ferrante, M. J.; Pankratz, L. B. Thermodynamic data for $\mathrm{Mg}(\mathrm{OH})_{2}$ (brucite). U.S. Bur. Mines, Rept. Invest. No. 8041, 1975.

8. Weller, W. W.; King, E. G. Low-temperature heat capacity and entropy at $298.15 \mathrm{~K}$ of muscovite. U.S. Bur. Mines, Rep. Invest. Nos. 6281 and 6371, 1963.

9. Pankratz, L. B. High-temperature heat contents and entropies of muscovite and dehydrated muscovite. U.S. Bur. Mines, Rep. Invest. No. 7369, 1964.

10. King, E. G.; Barany, R.; Weller, W. W.; Pankratz, L. B. Thermodynamic properties of forsterite and serpentine. U.S. Bur. Mines, Rep. Invest. No. 6962, 1967.

11. King, E. G.; Weller, W. W. Low-temperature heat capacities and entropies at $298.15 \mathrm{~K}$ of diaspore, kaolinite, dickite and halloysite. U.S. Bur. Mines, Rep. Invest. No. $5810,1961$.

12. Pankratz, L. B.; Kelley, K. K. High-temperature heat contents and entropies of akermanite, cordierite, gehlenite, and merwinite. U.S. Bur. Mines, Rep. Invest. No. 6555, 1964. 
13. Weller, W. W.; Kelley, K. K. Low-temperature heat capacities and entropies at $298.15 \mathrm{~K}$ of akermanite, cordierite, gehlenite, and merwinite. U.S. Bur. Mines, Rep. Invest. No. 6343, 1963.

14. Westrum, E. F., Jr.; Furukawa, G. T.; McCullough, J. P. Adiabatic low-temperature calorimetry. Experimental Thermodynamics Vol. I, chapter 5. McCullough, J. P.; Scott, D. W.: editors. Butterworths: London. 1968. p. 133.

15. West, E. D.; Westrum, E. F., Jr. Adiabatic calorimetry from 300 to $800 \mathrm{~K}$. In Experimental Thermodymanics Vol. I. McCullough, J. P.; Scott, D. W.:editors. Butterworths: London. 1968. p. 333.

16. Holm, J. L.; Kleppa, O. J.; Westrum, E. F., Jr. Geochim. Cosmochim. Acta 1967, 37, 2289.

17. Robie, R. A.; Krupka, K. Personal communication, August 1976.

18. Perkins, D., III; Essene, E. J.; Westrum, E. F., Jr. Cont. Mineral. Petrol. 1977, 64, 137.

19. Barany, R.; Kelley, K. K. Heats and free energies of formation of gibbsite, kaolinite, halloysite, and dickite. U.S. Bur. Mines, Rept. Invest. No. 5825, 1961. 